BHUMI: Jurnal Agraria dan Pertanahan

Received: July 29, 2021; Reviewed: November 3, 2021; Accepted: November 29, 2021.

To cite this article: Shabia, GNA. (2021). Kontribusi Community Supported Agriculture untuk Gerakan Agraria di Indonesia: Pelajaran dari Jerman, Bhumi, Jurnal Agraria dan Pertanahan, 7 (2), 181-198.

DOI: 10.3192/bhumiv7i2.490

Copyright: (이리 Gusti Nur Asla Shabia. All articles published in Jurnal Bhumi are licensed under a Creative Commons Attribution-ShareAlike 4.o International license.

Research Article

\title{
KONTRIBUSI COMMUNITY SUPPORTED AGRICULTURE UNTUK GERAKAN AGRARIA DI INDONESIA: PELAJARAN DARI JERMAN
}

\author{
Gusti Nur Asla Shabia \\ Fakultas Ilmu Budaya, Universitas Gadjah Mada \\ Jl. Nusantara 1, Bulaksumur Yogyakarta, 55281 \\ Koresponden E-mail: gustinurshabia@gmail.com
}

\begin{abstract}
Community Supported Agriculture (CSA) is a model of cooperation between food producers and consumers in carrying out agriculture that has emerged in Global North's countries. The establishment of CSA is related to the desire of a few people striving for a more equitable food system than the global and industrial food system which marginalizes the welfare of farmers. Building on the ethnographic study of the CSA Garten Coop in Freiburg, Germany, and comparing it with studies of CSA in other countries, this paper tries to explore the possibilities of how CSA can offer farmers an alternative agricultural model for the sustainability of their farm and its contribution to agrarian movement, especially in Indonesia. The results show that CSA provides this alternative through rearranging the food system with a more democratic, autonomous, and equal management of production resources, income certainty for farmers through consumer commitment and by the solidarity economy, and independence through the principles of sustainable agriculture. Therefore, CSA indirectly contributes to the agrarian movement by providing the possibility for farmers to maintain their farming business, along with their land tenure or ownership, as well as a forum for organizing farmers and consumers to raise awareness of the food system.
\end{abstract}

Keywords: Agrarian Movement, Community Supported Agriculture, Solidarity Economy, Producer-Consumer Partnership.

Intisari: Community Supported Agriculture (CSA) merupakan model kerjasama produsen dan konsumen pangan dalam menyelenggarakan pertanian yang banyak muncul di negara-negara Global Utara. Pendiriannya tak lepas dari keinginan segelintir orang mengupayakan sebuah sistem pangan yang lebih adil dari sistem pangan global dan industrial yang meminggirkan kesejahteraan petani. Dengan menggunakan studi etnografi pada komunitas CSA Garten Coop di Freiburg, Jerman dan membandingkan dengan studi-studi atas CSA di sejumlah negara lainnya, artikel ini disusun untuk menelusuri kemungkinan tentang bagaimana CSA dapat menawarkan model pertanian alternatif bagi petani untuk keberlanjutan usaha taninya dan kontribusinya terhadap gerakan agraria, terutama di Indonesia. Hasil penelitian menunjukkan bahwa CSA memberikan alternatif ini lewat pengaturan ulang sistem pangan dengan manajemen sumber daya produksi yang lebih demokratis, otonom, dan setara, kepastian pendapatan bagi petani lewat komitmen konsumen dan ekonomi solidaritas, serta independensi melalui prinsip pertanian berkelanjutan. Oleh karena itu, CSA secara tidak langsung berkontribusi dalam gerakan agraria dengan memberikan kemungkinan bagi petani untuk mempertahankan usaha taninya, berikut penguasaan atau kepemilikan lahannya, sekaligus wadah pengorganisasian petani dan konsumen untuk menumbuhkan kesadaran akan sistem pangan.

Kata Kunci: Community Supported Agriculture, Ekonomi Solidaritas, Gerakan Agraria, Kerjasama ProdusenKonsumen. 


\section{A. Pendahuluan}

Krisis agraria global, meskipun memiliki karakteristik dan bentuk yang berbeda-beda, menghadapi dua dari banyak permasalahan yang sama. Pertama, usaha membentuk pertanian global, di mana pertanian di banyak daerah disiapkan untuk memasok kebutuhan dunia dan bertransformasi menjadi lahan pangan skala luas, monokultur, industrial, dan intensif energi, serta kedua, munculnya jejaring luas industri pengolahan, perusahaan perdagangan besar, dan jejaring supermarket yang disebut "food empire" atau "imperium bisnis pangan" (McMichael, 2009a; Van der Ploeg, 2010). Imperium ini mengendalikan seluruh proses dari produksi hingga konsumsi dalam sistem pangan dan menentukan standar yang mengeksklusi petani dan pertanian-pertanian tertentu (Van der Ploeg, 2019).

Sebagai konsekuensi, pertanian skala kecil terdesak, sementara korporasi agribisnis yang efisien dan bisa memproduksi atau mengolah pangan secara masif memperoleh peran yang strategis dan menguat dalam keseluruhan rantai pangan (Kalfagianni \& Skordili, 2018; McMichael, 2020). Konsekuensi di banyak tempat adalah korporasi-korporasi ini dapat melakukan perampasan lahan yang masif, juga dapat mendesak petani dalam cara-cara yang lebih struktural dan sosial, seperti menyebabkan ketergantungan petani terhadap korporasi dalam keseluruhan rantai nilai dan menimbulkan kerusakan ekologis. Pola makan petani sebagai konsumen dapat turut berubah menjadi makanan-makanan instan yang merupakan produk dari agribisnis dan industri pangan yang murah karena kemiskinan dan daya beli mereka yang menurun.

Rumah tangga petani skala kecil lantas dihadapkan pada tiga opsi. Pertama, dipaksa menjual lahannya dan beralih ke kerja-kerja upahan, kedua, mempertahankan lahannya tetapi harus mengalami swaeksploitasi dan jebakan kemiskinan yang semakin parah, ketiga, memperjuangkan hak atas tanah mereka yang dapat diklaim melalui narasi keadilan dan keberlanjutan (McMichael, 20o9a) meskipun yang terakhir ini sering terbentur dengan permasalahan-permasalahan yang menyebabkan gerakan mereka terus dikerdilkan dan tidak berhasil mencapai tujuan yang diinginkan.

Hal inilah yang kemudian membuat munculnya berbagai gerakan pangan alternatif yang mencoba untuk menjawab permasalahan pangan dan agraria saat ini. Salah satunya adalah merebaknya Community Supported Agriculture atau CSA di Jerman dan beberapa negara lain di Amerika dan Eropa, yang secara khusus mengkritik sistem pangan global dan industrial yang semakin memarginalisasi dan menghilangkan petani kecil dan pertanian keluarga, merusak alam, dan membawa konsekuensikonsekuensi kesehatan terhadap konsumen (Feagan \& Henderson, 2009; Flora dan Bergendahl, 2012; Galt, 2011). CSA menawarkan model pertanian alternatif berbasis komunitas yang didasari dari prinsip lokalitas (locality) dan ekonomi solidaritas, di mana praktik-praktik produksi, distribusi, dan konsumsi dibuat berbeda dengan sistem pangan global.

Tulisan ini merupakan upaya untuk menelusuri CSA sebagai sebuah model pertanian alternatif yang lebih berkelanjutan bagi usaha tani petani dan meminimalisir keterdesakan mereka untuk menjual lahan, atau terlibat dalam kerjasama yang eksploitatif. Kemudian, pertanyaan lanjutan dari tulisan ini adalah: bagaimana CSA dapat berkontribusi pada gerakan agraria terutama di Indonesia? Meskipun CSA bukanlah gerakan yang secara murni berjuang dalam isu-isu redistributif seperti menuntut adanya reforma agraria dan bukan pula gerakan yang mengambil andil dalam politik praktis seperti melakukan advokasi kebijakan terhadap pemerintah (Fikri, 2015; Allen et al., 2003), pengubahan praktik-praktik dan relasi produsen-konsumen di dalam CSA menjadi salah satu hal yang bisa bermanfaat dalam gerakan agraria di Indonesia.

Temuan dari penelusuran ini menjadi penting, karena dalam tataran praktis, muncul keprihatinan dari aktivis-aktivis dan akademisi yang mencermati reforma agraria terkait model ideal seperti apakah yang harus dijalankan oleh petani agar akuisisi lahan tidak berulang kembali. Di Indonesia, ada skema yang dinamakan koperasi (coop), akan tetapi koperasi seringkali menjadi wadah ekstraksi perusahaan 
terhadap petani sehingga tidak mengentaskan permasalahan agraria (Li, 2021). Sementara, dalam tataran akademis, jarang sekali ada tulisan yang berusaha melihat kemungkinan kiprah CSA terhadap perjuangan agraria, terlebih di Indonesia, kecuali Holt-Giménez dan Shattuck (2011) yang membahas gerakan pangan secara umum. Tulisan-tulisan yang menganalisis dampak CSA terhadap produsen (Ostrom, 1997; Goland, 2002; Galt et al., 2011) sudah cukup banyak dan memberikan titik berangkat bagi analisis yang dibangun dalam artikel ini, tetapi usaha menghubungkan dengan diskursus agraria masih perlu dikembangkan.

Tidak ada teori khusus yang dipakai sebagai kerangka dalam mengonstruksikan analisis dalam tulisan ini, tetapi pijakan analisis kontribusi CSA terhadap gerakan agraria di Indonesia berangkat dari tiga hal, yakni posisi CSA sebagai gerakan antiglobalisasi, environmentalis, dan antikapitalisme yang dilihat oleh gerakan agraria sebagai "kawan" untuk memenangkan perlawanannya (Teubal \& Brena, 2019, McMichael, 2009a), ekonomi solidaritas sebagai prinsip yang diterjemahkan dalam praktikpraktik pengorganisasian ekonomi alternatif, dan "populisme agraria" (Borras, 2019) sebagai perjuangan bersama.

\section{B. Metode}

Sumber data untuk tulisan ini diperoleh melalui metode etnografi. Adapun sumber data yang dipakai dalam penulisan artikel ini memakai hasil penelitian etnografi dalam program riset tandem antara Universitas Gajdah Mada dan Albert-Ludwigs-Universität (ALU) Freiburg, pada Desember 2018-Maret 2019 di sebuah komunitas CSA bernama Garten Coop yang terletak di Freiburg dan desadesa sekitarnya. Freiburg merupakan sebuah kota kecil di negara bagian Baden-Württemberg, Jerman.

Pengumpulan data dilakukan melalui observasi partisipasi dengan mengikuti kegiatan Garten Coop baik di kebun komunitas, poin-poin distribusi di kota, dan lokasi penyelenggaraan acara komunitas, serta melalui wawancara mendalam yang dilakukan terhadap 9 informan. Pemilihan informan dilakukan berdasarkan latar belakang peran dan posisi mereka dalam Garten Coop: petani, anggota biasa ataupun yang tergabung secara aktif dalam struktur organisasi komunitas, dan anggota inisiator komunitas. Hampir seluruh informan dapat berbahasa Inggris sehingga membantu pengumpulan data, meskipun bahasa yang digunakan dalam kegiatan komunitas adalah bahasa Jerman sehingga kegiatan observasi partisipasi seringkali membutuhkan keikutsertaan peneliti warga asli (native) atau penerjemahan setelah kegiatan. Oleh karena itu, perekaman kegiatan juga dilakukan dengan terlebih dahulu disepakati bersama informan. Seluruh informan dalam tulisan ini, kecuali Luciano, ditulis dengan bukan nama sebenarnya (pseudonym).

Untuk menjembatani konteks Jerman dan Indonesia, artikel ini dilengkapi pula dengan analisis data sekunder dari buku, jurnal, dan data statistik (di antaranya, dari Badan Pusat Statistik) yang memuat data soal pertanian dan gerakan agraria di Indonesia selama kurang lebih 10 tahun terakhir untuk menjaga relevansi dengan kondisi terkini.

\section{Hasil dan Pembahasan}

\section{Pengorganisasian Sistem Pangan dalam CSA Garten Coop}

Pendirian Garten Coop sebagai sebuah CSA di kota kecil Freiburg di Jerman tidak bisa dilepaskan dari konteks sejarahnya. Secara historis, CSA pertama-tama muncul di tiga negara berbeda, termasuk di Jerman, dengan alasan yang serupa dan berangkat dari motivasi ekologis.

Gerakan Teikei di Jepang, sebagai akar CSA masa kini, muncul dari kekhawatiran masyarakat terhadap pencemaran lingkungan oleh bahan kimia, termasuk input kimia yang dipakai dalam pertanian 
industrial. Sementara, gerakan organik di Jerman dan Swiss merupakan nenek moyang CSA di kedua negara tersebut, yang turut mengikutsertakan prinsip solidaritas karena banyak terinspirasi dari gerakan solidaritas pekerja-petani dan kebun kolektif di Prancis dan Chili (Henderson, 2010; Japan Organic Agriculture Association, n.d.). Setelah itu, CSA mulai menyebar ke banyak negara termasuk di Freiburg. Garten Coop merupakan CSA pertama di kota ini. Dalam bahasa lokal, istilah CSA lebih dikenal sebagai Solidarische Landwirtschaft atau diterjemahkan secara literal berarti "Pertanian Bersolidaritas".

Pendirian Garten Coop, meskipun tetap terkait dengan kritik atas sistem pangan global yang eksploitatif dan tidak berkelanjutan, didasari oleh refleksi pendiri-pendirinya, Luciano dan Lucas, terhadap "Gerakan Keadilan Global” melawan kebijakan-kebijakan neoliberalisme dalam sistem pangan yang mereka ikuti. Gerakan yang mengandalkan aksi konfrontatif seperti protes dan demonstrasi ini dianggap Luciano tidak cukup untuk mendongkrak perubahan secara personal dan menciptakan struktur alternatif yang berkelanjutan (wawancara dengan Luciano, 11 Januari 2019). Sehingga, Luciano berpikir untuk menciptakan gerakan alternatif yang lebih dekat dengan keseharian dan merangkul masyarakat secara lebih luas. Ide ini sangat lekat dengan gerakan sosial baru (New Social Movement) yang memandang bahwa landasan gerakan berangkat dari premis bahwa "personal is political" (keseharian merupakan hal yang politis) (Pichardo, 1997).

Persentuhan Luciano ketika masih aktif dalam gerakan keadilan global pun membuatnya banyak bersinggungan dengan gerakan dengan gerakan petani, kedaulatan pangan, dan agraria global, seperti La Via Campesina dan Movimento dos Trabalhadores Sem Terra (MST). Ini membuatnya berpikir gerakan alternatif yang diciptakan harus berjuang dalam isu kedaulatan pangan sebagai cara untuk membangun kembali sistem pangan yang dikehendaki. Kedua gerakan tersebut juga mengenalkannya pada prinsip "solidaritas” yang dijadikan sebagai landasan mengorganisasikan praktik-praktik di Garten Coop. Setelah membentuk tim kecil inisiator beranggotakan 15 orang, menemukan lahan di Desa Tunsel yang berjarak $20 \mathrm{~km}$ dari kota, dan memperoleh anggota konsumen yang cukup untuk menjalankan kegiatan pertanian, Garten Coop kemudian resmi beroperasi pada tahun 2011, menawarkan sayur sebagai komoditas utama (Shabia, 2019).

Sebagai komunitas, Garten Coop merumuskan berbagai prinsip yang disepakati bersama anggotaanggotanya. Prinsip-prinsip ini banyak ditemukan di CSA di seluruh dunia secara umum (Medici et al., 2021; Feagan dan Henderson, 2009; Goland, 2002). Prinsip-prinsip tersebut adalah (1) pertanian ekologis dan hemat sumber daya, (2) pengorganisasian secara mandiri dan akar-rumput, (3) solidaritas sebagai landasan seluruh praktik, (4) , tanggung jawab yang tinggi bagi seluruh bentuk keterlibatan anggota, dan (5) anti-rasis, anti-seksisme, dan menekan hierarki serendah mungkin (Garten Coop, 2018a). Prinsip-prinsip ini sebenarnya merupakan cara Garten Coop mengoperasionalisasikan kritik mereka terhadap sistem sosial dan ekonomi kapitalis global yang menurut mereka menyebabkan permasalahan global seperti kelangkaan sumber daya, peningkatan kemiskinan dan kelaparan, privatisasi tanah, dan eksploitasi tenaga kerja, juga permasalahan personal yang "disebabkan oleh kapitalisme" seperti pola pikir dan perilaku individu yang didasarkan kompetisi (Garten Coop, n.d).

Prinsip ini kemudian digunakan untuk melandasi praktik-praktik produksi, distribusi, dan konsumsi, berikut relasi antara aktor-aktor yang terdapat di Garten Coop, meskipun ketiga proses dan relasi ekonomi yang tercipta di Garten Coop harus seringkali dinegosiasi secara terus-menerus di antara anggota sesuai dengan dinamika di internal, karena menyatukan keinginan, pola pikir, dan perilaku ratusan anggota, baik petani maupun konsumen, bukan hal yang mudah (Shabia, 2019).

Oleh sebab itu Garten Coop memiliki struktur organisasi berdasarkan fokus kerja dan forum penciptaan keputusan yang diorganisasi secara rutin, setiap dua minggu. Anggota yang tergabung dalam struktur organisasi, di luar anggota petani, merupakan kunci dari berjalannya kegiatan organisasi berikut proses produksi, distribusi, dan konsumsi. Mereka kerap disebut sebagai “Tim Inti”, penghubung antara 
kebutuhan petani dan konsumen (Goland, 2002). Bahkan, para anggota dari salah satu kelompok kerja "C-Team" dipilih secara kolektif dan harus memiliki latar belakang studi hukum, karena kerja mereka terkait dengan kontrak, rekrutmen, dan kondisi kerja petani. Beberapa dari Tim Inti memperoleh insentif untuk kerja yang mereka kontribusikan.

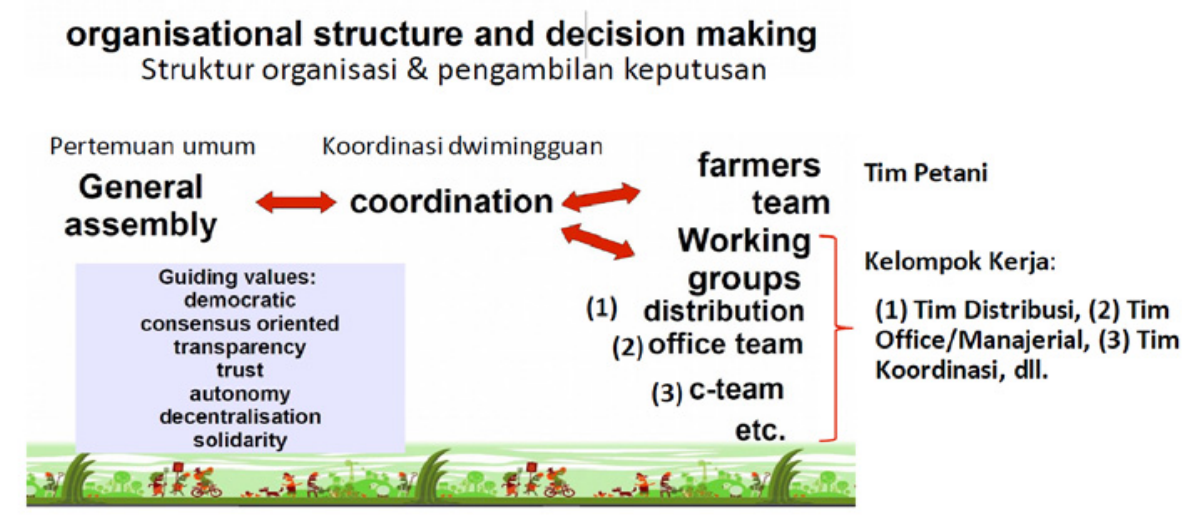

Gambar 1. Struktur Organisasi dan Pengambilan Keputusan di Garten Coop Sumber: Presentasi Garten Coop, 2018, penerjemahan oleh penulis

Dalam produksi, Garten Coop pertama-tama mengandalkan keseluruhan biaya produksi dari iuran anggota. Patut dipahami bahwa sistem pasar yang ada di dalam Garten Coop adalah "sirkuit tertutup", di mana "pembeli" adalah anggota konsumen. Produk tidak dipasarkan di luar komunitas kecuali untuk didonasikan. Oleh karena itu, jalannya kegiatan pertanian mengandalkan sokongan finansial dari iuran anggota, dengan penghitungan yang didasarkan pada:

keseluruhan biaya produksi (sarana produksi +

sewa lahan + alokasi upah tetap untuk petani +

biaya operasional tim inti + transportasi +

= iuran anggota

perawatan + biaya tak terduga)

total jumlah anggota.

Penghitungan di atas merupakan penghitungan klasik di banyak CSA, meskipun di Garten Coop telah disepakati sebuah mekanisme di mana anggota dengan kemampuan ekonomi rendah yang tidak mampu membayar iuran rata-rata tersebut dapat membayar kurang. Namun, harus ada anggota yang membayar kelebihan yang tak tertutup iuran anggota berekonomi rendah ini.

Penghitungan ini biasanya dilakukan dalam "Putaran Penawar" (Bieterrunde) di bulan Desember setiap tahunnya, berbarengan dengan rapat besar awal musim tanam, untuk mengawali masa keanggotaan yang berlangsung selama satu tahun. Dalam keseluruhan biaya produksi tersebut, petani memperoleh upah tetap yang dilandaskan pada jam kerja dan bukannya hasil pertanian. Garten Coop tidak ingin menerapkan pengupahan petani dari hasil panen yang seringkali kegagalan/keberhasilannya dipengaruhi oleh faktor eksternal di luar kendali petani, seperti perubahan iklim, cuaca, dan serangan hama. Tanggungan bersama terhadap satu kegiatan pertanian juga berpengaruh kepada status kepemilikan, di mana Garten Coop selalu menekankan bahwa kebun beserta properti yang ada di atasnya adalah milik kolektif.

Biaya produksi di Garten Coop bisa ditekan kurang dari biaya produksi pertanian konvensional dengan cara industrial karena mereka memakai sistem pertanian alami dan rantai distribusi yang amat pendek. Produksi kompos mandiri dan pupuk hijau (green manure) membuat mereka tidak perlu membeli pupuk kimia yang mahal. Mereka masih membeli benih murni hasil pemuliaan usaha kecil 
setempat (Shabia, 2019) yang tetap memberi harga yang terjangkau. Garten Coop juga tidak memiliki rumah kaca berpemanas atau lemari pendingin, dua buah teknologi yang biasanya digunakan untuk menyiasati cuaca dan mengawetkan kesegaran komoditas, karena prinsip "musiman" (seasonal). Sayur, buah, dan rempah-rempah yang ditanam komunitas ini mengikuti siklus musim dan tidak dipaksakan tumbuh di luar musimnya, sehingga tidak membutuhkan teknologi yang intensif energi sebagaimana yang terjadi di kebun-kebun pertanian besar. Oleh karena itu, pertanian alami bukan saja menjadi prinsip, tetapi menjadi strategi ekonomi untuk menekan anggaran.

Untuk distribusi, hasil panen setiap minggu akan langsung didistribusikan ke anggota dalam keranjang-keranjang panen. Distributornya adalah anggota konsumen sendiri, yang melakukannya dengan sukarela. Setiap minggu akan ada satu mobil boks yang membawa hasil panen dari kebun di Desa Tunsel ke tengah kota Freiburg, yang kemudian diantar dengan sepeda ke 17 titik yang tersebar di beberapa distrik di kota. Di 17 titik ini, masing-masing konsumen akan mengambil jatah mingguan mereka.

Karena dibutuhkan dua pengemudi mobil box dan 34 pesepeda (dengan perhitungan 17 titik memerlukan dua sepeda untuk memudahkan pengangkutan keranjang), penentuan sukarelawan ditentukan jauh-jauh hari melalui situs web komunitas. Koordinasi seperti ini lah yang menimbulkan kebutuhan bahwa anggota harus memberikan partisipasi aktif, karena tanpa bantuan mereka, hasil panen takkan sampai ke kota dan tidak dapat diambil oleh anggota.

\section{7 food collection points}

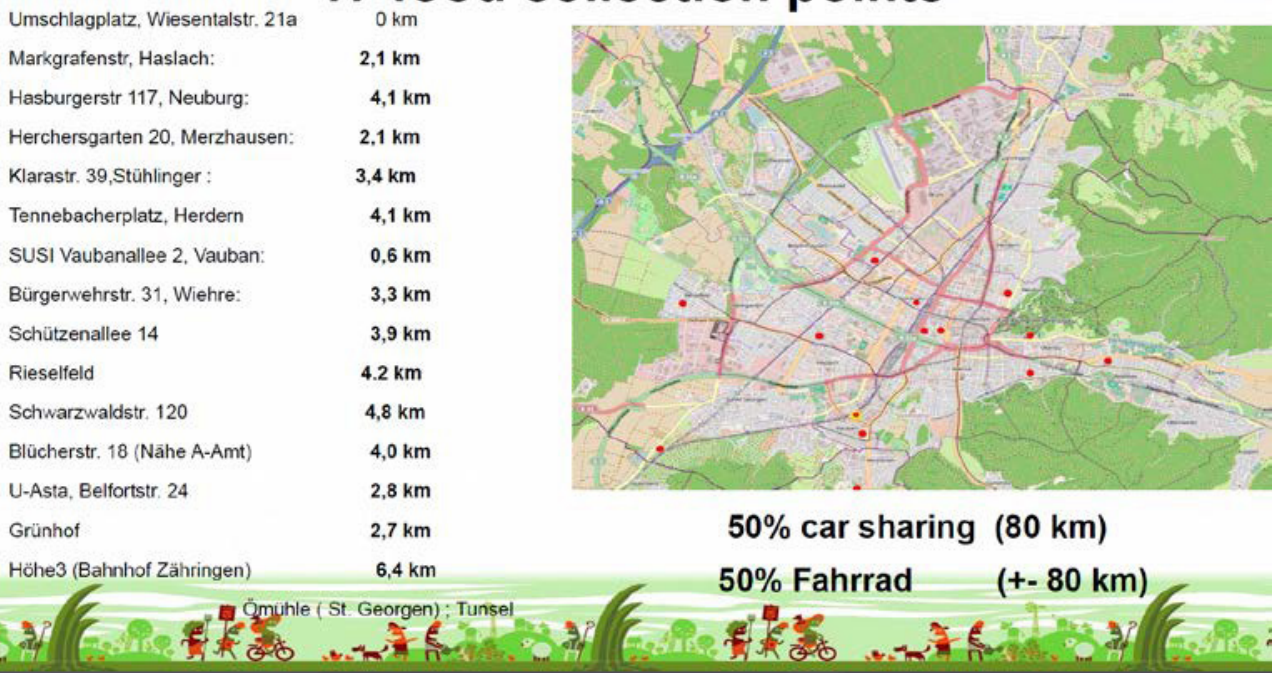

Gambar 2. 17 Titik Pengantaran Hasil Panen

Sumber: Presentasi Garten Coop (2018)

Keranjang hasil panen yang sampai di titik terakhir pengantaran akan menjadi wadah paling minimal seorang anggota untuk berpartisipasi, karena anggota harus mengambil sendiri jatah mereka tepat waktu, menimbang hasil panen secara mandiri, dan membawanya pulang dengan wadah sendiri. Dari sisi konsumsi, tidak banyak hal yang diatur oleh Garten Coop, selain komunitas ini berharap bahwa cara produksi dan distribusi yang diubah dan tidak dibentuk seperti sistem pangan konvensional yang serba nyaman dan instan, membuat anggota merefleksikan pangannya, termasuk memasaknya. Garten Coop mengkritik kecenderungan masyarakat yang kini lebih memilih produk take-out, junk food, dan makanan ultraproses yang lebih praktis, efektif, dan mendukung ritme kehidupan yang cepat (Folbre, 2013), tetapi merupakan bagian dari "imperium bisnis pangan" (Van der Ploeg, 2010) dan menimbulkan konsekuensi kesehatan bagi konsumen. Hal ini dikarenakan industri pengolahan dan jejaring supermarket mengakses pangan murah dari pertanian industrial berskala besar. Ini juga 
merupakan tindakan kontra dari fenomena homogenisasi pola makan dan budaya konsumen pangan global (McMichael, 2009a).

Dalam tataran konsumsi ini, pendidikan kritis digarisbawahi oleh Garten Coop dari beberapa aspek. Pertama, aspek makanan musiman, yang membuat mereka menyadari bahwa sebagian besar makanan yang tersedia di pasar swalayan dan yang mereka konsumsi banyak yang merupakan produk impor. Bahwa banyak makanan lokal yang sudah tergerus dalam pola konsumsi populer masa kini, sehingga tidak dikenali dalam konsumsi sehari-hari.

Kedua, aspek makanan "berwajah”. Dalam rantai pasok yang panjang dan rumit, konsumen terbiasa memperoleh makanan yang disebut "food from nowhere" (McMichael, 2009b). Partisipasi aktif anggota selain melakukan proses distribusi, adalah turut ikut dalam kegiatan produksi di kebun bersama petani, seperti mencangkul, menyemai, menanam, memanen, membawa keranjang yang berat, seringkali dilakukan dalam situasi cuaca yang ekstrem, seperti suhu di bawah o derajat di musim dingin atau di bawah panas matahari yang membakar.

Menurut penuturan anggota, dengan berpartisipasi, mereka tidak hanya jadi mengenal petani, tetapi juga memahami dan mengalami kerja keras mereka (wawancara dengan Wolf, 12 Februari 2019; wawancara dengan Julian, 6 Februari 2019). Pangan telah membuat mereka menyadari bahwa setiap makanan memiliki apa yang disebut McMichael (2009b) “... konjungtur historis yang diikutsertakan prinsip-prinsip yang kontradiktif”. Setidaknya, di Garten Coop anggota konsumen bisa memastikan hal-hal kontradiktif itu terminimalisir sedemikian rupa dan ikut bertanggungjawab terhadap proses produksinya. Wolf satu kali pernah menceritakan pemahaman akan perubahan iklim menjadi "lebih dekat dengan kehidupannya" karena kentang yang ia terima kecil-kecil, dan di saat yang sama, petani Garten Coop mengeluhkan bahwa musim hujan yang datang terlambat dari estimasi telah berkontribusi pada pertumbuhan tanaman.

\section{Ekonomi Solidaritas untuk Petani}

Ekonomi Solidaritas menjadi landasan ekonomi yang diadopsi di dalam Garten Coop, terlihat dari praktik-praktik produksi, distribusi, dan konsumsi yang berjalan. Dari tulisan Fikri (2015) dilihat bahwa ekonomi solidaritas merupakan kerangka kerja Garten Coop yang diterjemahkan dalam tiga praktik, seperti berbagi (sharing) biaya, risiko, dan kerja (division of labour), dan ditambahkan dari tulisan Shabia (2019) bahwa proses berbagi pengetahuan dan perasaan "berkomunitas" merupakan bagian penting dari ekonomi solidaritas Garten Coop.

Ekonomi solidaritas ini lah yang kemudian mengantarkan signifikansi CSA sebagai model alternatif yang dapat memberikan kedaulatan dan penghidupan yang lebih baik bagi petani. Pertanyaan agraria (agrarian questions) dari Bernstein (2019, pp. 30-32): siapa memiliki apa, siapa mengerjakan apa, siapa memperoleh apa, dan digunakan untuk apa hasil yang mereka dapatkan itu, dapat dijadikan sebagai cara menganalisis manfaat CSA bagi petani.

Untuk siapa memiliki apa, sejauh ini dapat dilihat bahwa petani di Garten Coop yang sebenarnya serupa dengan petani penggarap, karena kepemilikan lahan tetap ada di tangan pemilik lahan yang disewakan untuk Garten Coop, sementara komunitas hanya menyewa lahan secara kolektif. Hal ini berimplikasi pada hak yang dimiliki petani adalah hak untuk mengakses dan menguasai secara fisik. Selain lahan, hampir seluruh properti di kebun dibeli oleh uang komunitas dan dijadikan milik bersama. Sedangkan untuk modal, modal merupakan iuran kolektif yang sumbernya dari anggota yang dihimpun hanya untuk diorganisasi oleh tim inti. Jumlah modal sangat tergantung dengan biaya produksi dan jumlah anggota. 
Terkait siapa mengerjakan apa, telah dijelaskan bahwa petani tetap menjadi produsen yang menggarap kebun untuk memenuhi kebutuhan anggota. Mereka tetap melakukan kerja-kerja pertanian pada umumnya; mencari benih dan bibit, menyusun kalender tanam, menghitung anggaran untuk satu musim tanam atau analisis usaha tani, mencari alternatif sumber pendanaan dari pemerintah yang bisa dimanfaatkan, menyeleksi sayuran yang layak didistribusikan, dan mengurus pengorganisasian kerja di antara mereka. Perbedaan hanya terletak pada ketiadaan "bos" karena prinsip anti-hierarki yang Garten Coop implementasikan.

Petani juga mengemban tanggung jawabedukasi juga terutama terkait pertanian berkelanjutan. Tidak semua petani yang masuk ke Garten Coop familier dengan pertanian berkelanjutan untuk diterapkan, sehingga harus ada pertukaran pembelajaran antara petani lama dan petani baru sebelum petani baru terintegrasi secara penuh. Petani juga memiliki tanggung jawab terhadap kegiatan komunitas, seperti membimbing kegiatan pertanian untuk anggota yang membantu di kebun dan membuat Newsletter mingguan yang melaporkan kegiatan pertanian, kendala dan kemudahannya, dan rencana panen untuk minggu yang akan datang.

Di luar hal ini, ditemukan bahwa pola pekerjaan petani Garten Coop mirip dengan petani skala kecil di Indonesia yang tidak bekerja dalam jam kerja penuh (full time) dan harus merangkap pekerjaan lain. Data lapangan tidak sempat menemukan apakah mereka mengiringi kerja Garten Coop dengan pekerjaan lain yang bukan dalam pekerjaan non-tani, tetapi beberapa penelitian tentang CSA menunjukkan bahwa petani CSA masih memiliki pekerjaan lain, umumnya masih terkait pertanian atau pangan, di luar pekerjaan CSA-nya, meskipun sumber pendapatan utama beberapa petani masih bersumber dari gaji yang diperoleh dari CSA (Medici et al., 2021; Galt, 2011; Ostrom, 2007; Hinrichs, 2000).

Anggota mengerjakan tanggung jawabnya yang utama: menyokong pekerjaan petani dengan iuran mereka dan berpartisipasi aktif dalam kegiatan produksi dan distribusi. Bagi mereka yang tergabung dalam tim inti, mereka membantu petani dalam urusan manajerial seperti pengurusan tanah, administrasi dengan pemerintah lokal, pendataan konsumen yang berpengaruh pada usaha tani, dan subsidi pemerintah.

Terkait siapa mendapatkan apa, di titik ini lah CSA mungkin akan banyak menggambarkan kontribusi bagi petani. Pertama, petani memperoleh upah berupa "gaji tetap" yang merupakan gaji bersih yang tak dipengaruhi hasil panen maupun produktivitas. Data lapangan tidak mengumpulkan data gaji perseorangan di Garten Coop, tetapi gambaran gaji petani dari CSA lain di wilayah Freiburg juga, yakni Lebensgarten, dapat menunjukkan bahwa gaji di CSA relatif lebih tinggi dari gaji di perusahaan pertanian lain, yakni 2.60o Euro (CSA) banding 2.370 Euro (pertanian konvensional) (Shabia, 2019). Garten Coop tidak pernah melakukan komparasi langsung dengan pendapatan petani penggarap yang misalnya, bermitra dengan perusahaan pertanian, tetapi Luciano dan beberapa petani selalu menggarisbawahi bahwa ketidakstabilan pendapatan petani bukan sesuatu yang akan terjadi di Garten Coop karena tidak ada standarisasi pasar.

Sedangkan untuk surplus, karena prinsip Garten Coop bukan hanya berbagi risiko, tetapi juga kelebihan panen, membuat mereka menyerap hasil panen itu kembali ke komunitas dalam bentuk makanan dan tidak diuangkan. Komoditas ini lantas dibagikan kepada anggota petani dan anggota konsumen. Sebagaimana kata Bernstein (2019) hasil kerja yang dihargai tidak melulu berwujud uang dalam konteks kapitalisme hari ini, di mana petani memperoleh pangan dan juga surplusnya, tetapi yang juga penting bagi petani: tempat mempelajari pertanian alami sekaligus melakukan aktivisme dengan pendapatan yang stabil.

Banyak petani di Garten Coop sebenarnya tidak menghargai pendapatan sebatas keuntungan ekonomi. Seorang petani bernama Fritz mengungkapkan bahwa Garten Coop dapat menjadi sebuah tempat ia belajar sembari memperoleh pendapatan yang pantas untuk "beralih ke tujuan selanjutnya" 
(Wawancara dengan Fritz, 27 Februari 2019). Ia merefleksikan pengalamannya mengawali usaha pertanian bersama kawan-kawannya yang ternyata sulit. Petani lain bernama Charlotte menilai CSA membuatnya bisa memproduksi pangan untuk konsumen yang ia kenali, dengan tekanan kerja yang lebih rendah dan toleransinya lebih tinggi, sesuatu yang berbeda apabila ia memproduksi pangan untuk "big client" (Wawancara dengan Charlotte, 8 Februari 2019). Petani lain bernama Xenia bekerja di CSA karena tertarik mempelajari pertanian alami yang diiringi dengan "kerja sosial" (Wawancara dengan Xenia, 31 Januari 2019).

Irisan dari tiga hal ini adalah Garten Coop memberi tempat bagi petani-petani muda untuk belajar dan bekerja dalam pertanian alami tanpa kekhawatiran akan kerugian, tekanan, dan tuntutan, tepatnya melalui jaminan pengorganisasian ekonomi juga relasi sosial yang berlangsung di Garten Coop. Ini juga merupakan manfaat CSA bagi petani yang ditemukan di dalam CSA-CSA lain (Partszch, 2018).

Apa yang didapatkan petani merupakan ekonomi solidaritas juga, yang mungkin takkan mereka jumpai dalam kerja-kerja yang berhubungan dengan perusahaan pertanian industrial skala besar dan masif, seperti memproduksi untuk "big client" yang disinggung Charlotte. Penggambaran Charlotte merujuk pada pertanian kontrak (contract farming) yang walaupun skema kerjasamanya kontraktual tapi kontrak masih sering dimanipulasi dan penuh standar-standar yang akan menekan petani-secara ekonomi dan sosial—dan tidak menoleransi kegagalan panen (Ray et al., 2021; Eaton dan Shepherd, 2001). Artinya, kerjasama yang berlangsung tidak setara dan kekuasaan lebih berlangsung di tangan korporasi.

Sementara, terkait aktivisme yang dikatakan oleh Xenia, ini berhubungan pula dengan siapa mengerjakan apa di mana petani Garten Coop memberikan edukasi soal pertanian dan permasalahannya dari kegiatan bersama di kebun atau via Newsletter. Ekonomi solidaritas telah menempatkan semua kegiatan ekonomi dan relasi sosial saling terhubung, dilandaskan relasi yang saling mengenal.

Relasi ini yang juga membuat gaji petani di Garten Coop nyaris tak pernah diubah nominalnya meskipun komunitas sedang dalam masa kekurangan anggota. Beberapa anggota merasa setelah melihat langsung dan membaca melalui Newsletter soal kerja keras petani dan kerja pertanian yang sulit, tidak mungkin mereka dibayar lebih rendah, karena petani tetap memberikan tenaga yang besar. Meskipun begitu, perlu dikritisi bahwa anggota dapat memberikan komitmen seperti ini karena banyak di antara mereka berasal dari kelas ekonomi menengah dan menengah ke atas, pun teredukasi, sehingga mereka mampu menyisihkan pendapatannya. Dalam hal ini, siapa mendapat apa terlihat dari temuan bahwa petani juga memperoleh jaminan ekonomi dari anggota konsumen yang berkomitmen, berkesadaran (conscious), bersolidaritas, dan mampu secara ekonomi.

Terkait pertanyaan agraria yang terakhir, digunakan untuk apa hasil yang didapat, petani menggunakan pendapatan yang diperoleh sebagai gaji bersih (karena sisa biaya produksi lainnya sudah ditanggung komunitas) untuk biaya konsumsi. Dalam hal ini, terlihat ciri CSA yang mendekomodifikasi pangan dan tidak berniat untuk melakukan akumulasi profit, bahkan dari surplus yang dihasilkan.

Melihat bagaimana petani di Garten Coop menghargai manfaat CSA dan bagaimana pembagian kerja, relasi sosial, dan prinsip ekonomi dibentuk untuk memenuhi kebutuhan petani ini, tak bisa dilepaskan dari konteks Jerman dan permasalahan agrarianya. Jerman merupakan negara dengan ekonomi post-industrial yang kebijakan ekonominya dipengaruhi kerjasama Uni Eropa termasuk dalam bidang pertanian dalam bentuk Common Agricultural Policy (CAP). CAP memberikan skema subsidi yang lebih mendukung pertanian skala besar yang berimplikasi pada dominasi pertanian skala besar yang dapat melakukan perampasan lahan, sementara petani skala kecil semakin sulit bertahan apalagi mengembangkan lahan pertanian mereka (lihat Van der Ploeg, 2019; McMichael, 2020). CAP juga membuat perusahaan transnasional dalam bidang agrokimia dapat memasarkan benih GMO, pestisida, 
pupuk, dan teknologi pertanian buatan yang mengancam keberlangsungan ekologis dan pertanian skala kecil.

Meskipun permasalahan-permasalahan agraria di Jerman ini tetap menuntut adanya redistribusi tanah dan juga kedaulatan pangan sebagai kontra gerakanyang melawan kuasa perusahaan transnasional, konteks negara post-industrial atau post-materialisme dengan perekonomian yang banyak penduduknya sudah berpendapatan menengah ke atas juga berpengaruh terhadap corak gerakan sosial yang tumbuh di dalam negara tersebut (Buechler, 2013). Gerakan sosial ini disebut "Gerakan Sosial Baru” atau gerakan yang menitikberatkan perjuangan atau kritik dengan mengubah keseharian atau hal-hal kultural karena personal is political, sehingga perjuangannya lebih mencari otonomi, demokratisasi, serta kualitas kehidupan (Pichardo, 1997; Melucci, 1980; Buechler, 2013). Oleh karena itu, seringkali partisipan atau pendukung gerakan bukan hanya dipersatukan oleh kelas, tetapi oleh identitas atau perhatian terhadap isu tertentu. Fikri (2015) dalam hal ini, melihat Garten Coop merupakan Gerakan Sosial Baru.

Gerakan Sosial Baru mungkin merupakan teori yang dapat menjelaskan karakteristik Garten Coop yang anggotanya banyak dipersatukan oleh identitas yang sama sebagai aktivis pangan, bahkan petaninya yang bukan petani kaum tani (peasant farmers). Namun, hal ini menunjukkan posisi CSA sebagai sesuatu yang dapat dikritik dengan karakternya sebagai Gerakan Sosial Baru, yang arahnya memang tidak seperti gerakan memperjuangkan redistribusi ekonomi demi terjaminnya kebutuhan dasar atau hanya dapat melibatkan orang-orang dari kelas tertentu saja.

Di beberapa artikel, CSA sudah dikritik karena iuran anggota terlampau mahal sehingga hanya menarik konsumen perkotaan yang mampu (Ostrom, 2007; Hinrichs \& Kremer, 2002; Plank et al, 2020), meskipun Garten Coop menciptakan strategi mengikutsertakan konsumen yang "tidak mampu". Bentuk CSA terdiskoneksi karena gerakannya tidak membedah permasalahan struktural dalam sistem pangan, seperti memerhatikan akses masyarakat kurang mampu terhadap makanan sehat (HoltGiménez dan Shattuck, 2011; Allen et al., 2003). Lantas apakah model CSA seperti Garten Coop tidak dapat menimbulkan perubahan ataupun kontribusi yang signifikan dalam mengubah sistem pangan, terutama bila diduplikasikan ke negara lain?

Poin soal ekonomi solidaritas yang diterjemahkan dalam tiga praktik, seperti berbagi (sharing) biaya, risiko, kerja (division of labour), pengetahuan dan perasaan "berkomunitas" (Fikri, 2015; Shabia, 2019) tetap harus dilihat sebagai kunci yang dapat membuat CSA tetap relevan di banyak tempat yang kurang lebih menghadapi permasalahan pangan dan agraria yang serupa. Apalagi, setiap CSA memiliki potensi untuk dikembangkan menjadi bentuk yang berbeda, menyesuaikan dengan konteks dan lokalitas yang berbeda (Schlicht, 2014). Di kota Freiburg sendiri, terdapat satu CSA bernama "Luzernenhof" yang baik tata kelola maupun akar pendiriannya berbeda dari Garten Coop, di mana CSA ini terbentuk untuk mempertahankan lahan pertanian keluarga yang dikelola dengan pertanian alami dari keterancaman dijual (Partszch, 2018).

Selain itu, tujuan CSA untuk menciptakan pertanian yang lebih ramah lingkungan, membentuk sebuah sistem pangan alternatif, dan melawan sistem pangan global yang berdampak pada negara-negara Global Utara dan Global Selatan, dapat diseiringkan dengan perjuangan gerakan agraria yang sifatnya lebih ke pengubahan secara struktural, termasuk di Indonesia. Bagian selanjutnya akan membahas ini, dengan terlebih dahulu memahami konteks permasalahan pangan dan agraria di Indonesia.

\section{Pertanian Solidaritas bagi Gerakan Agraria di Indonesia: Sebuah Potensi}

Permasalahan agraria di Indonesia saat ini sangat kompleks dan bersifat struktural, dan menunjukkan bahwa lahan pangan yang dikuasai petani skala kecil semakin berkurang. Misalnya, BPS (2019a) menunjukkan bahwa terjadi peningkatan jumlah petani gurem di Indonesia, sebanyak 1,6 juta rumah tangga, selama lima tahun sejak 2013. Ketimpangan penguasaan tanah juga terjadi, kurang lebih 59\% dari 
keseluruhan rumah tangga usaha pertanian pengguna lahan adalah petani gurem, sedangkan pemilik lahan di atas 10 hektar tidak mencapai 1\% (BPS, 2019a). Ini baru dalam taraf penguasaan (holder), bukan kepemilikan (owner), yang artinya di antara mereka adalah petani-petani penggarap yang menyewa lahan dari tuan tanah.

Berkurangnya lahan pangan yang dikuasai petani kecil dapat terjadi karena proses perampasan lahan karena terdapat pencaplokan lahan (land grabbing) (Li, 2011), tetapi dapat terjadi juga dalam perubahan hubungan-hubungan kapital baru yang terjadi sehari-hari, di mana terdapat petani yang gagal bersaing dalam hubungan-hubungan baru tersebut dan tidak memperoleh penghidupan yang layak, tepatnya ketika ia tidak dapat mengakumulasi lahan dan modal serta mengefisiensikan tenaga kerja untuk memperbesar keuntungan dan kuasa (Li, 2020; Neilson, 2016). Perampasan yang terakhir kemudian memaksa seorang petani-seringkali petani gurem-untuk menjual lahannya dan/atau kemudian, tenaganya.

Untuk permasalahan yang kedua, segelintir petani tidak dapat mengakumulasi modal apalagi lahan terutama karena beberapa hal. Pertama, karena relasi tenurial yang timpang, tepatnya ketika seorang petani penggarap menyewa tanah dari tuan tanah dengan prinsip bagi hasil, baik dengan maro (proporsi setengah hasil panen) ataupun mertilu (proporsi sepertiga hasil panen) (Ambarwati et al., 2014). Dalam kondisi ini, seringkali petani memperoleh biaya sewa yang tinggi dan tuan tanahnya sama sekali lepas tangan dalam biaya produksi. Kedua, ketergantungan petani terhadap input eksternal yang mahal seperti pupuk kimia, sehingga bila terjadi kelangkaan subsidi, mereka rentan menanggung biaya input yang tinggi. Ketiga, harga komoditas yang fluktuatif di pasaran yang berpengaruh terhadap harga jual panen petani di pedagang pengumpul/tengkulak yang jatuh. Padahal, tengkulak masih menjadi sumber penyerapan hasil panen petani paling besar (BPS, 2017; BPS, 2019b).

Terakhir, adanya liberalisasi pangan yang semakin masif, di mana pangan impor yang masuk ke pasaran akan berpengaruh pada harga jual petani yang jatuh di pasaran karena harga komoditas impor yang lebih murah. Ketiga permasalahan terakhir bukan hanya menjadi permasalahan petani penggarap, tetapi juga petani gurem. Kombinasi ini membuat petani menanggung biaya produksi yang besar dan masih harus menghadapi ketidakpastian pasar. Pemasukan tidak membawa keuntungan, bahkan seringkali membuat petani merugi, terlebih mereka yang meminjam uang untuk menutup biaya produksi terlebih dahulu.

Di tengah keterhimpitan itu, perusahaan agribisnis dan proyek pemerintah yang mendukung kebun pangan monokultur skala luas hadir sebagai tawaran penyelamat bagi petani, terlebih agar mereka dapat mengakses modal dan pasar yang lebih kuat. Pemerintah, sebagai bagian dari negara yang memiliki kewajiban melindungi hak-hak petani, malah turut menciptakan kebijakan yang menambah permasalahan agraria, di antaranya melalui Food Estate. Padahal, Food Estate dengan program korporasi petaninya merupakan skema yang tetap mengekstraksi tenaga kerja petani untuk akumulasi profit di tangan perusahaan yang menyerap hasil panen (offtaker). Food Estate juga mengintegrasikan petani ke dalam sirkuit kapital global melalui agenda ekspor. Hal ini diperunyam dengan adanya pengesahan peraturan UU No. 11 Tahun 2020 tentang Cipta Kerja, yang dipandang banyak lapisan masyarakattermasuk aktivis dan gerakan agraria—tidak mengusahakan reforma agraria yang dikehendaki. Alih-alih, regulasi ini dianggap akan semakin mempermudah perampasan lahan skala luas maupun perampasan yang terjadi karena akumulasi sehari-hari tadi.

Dengan permasalahan yang pelik dan negara yang semakin bersisian dengan kepentingan pasar dalam pengaturan sistem pertanian berikut petaninya, CSA dapat memberikan model alternatif bagi petani untuk bertahan dari kerentanan, terlebih terhadap petani gurem yang hanya memiliki pilihan untuk "menjual tanah dan beralih untuk menjual tenaganya" serta petani penggarap yang mengalami kesulitan untuk bertahan dengan ketimpangan relasi tenurial yang telah disinggung di atas (lihat 
Tabel 1). Hal ini dikarenakan CSA bisa membantu seorang petani untuk memperoleh pemasukan yang lebih stabil dan tak bergantung dengan pasar (berikut standardisasi, hukum permintaan-pengeluaran, persaingan dengan produk impor, dst). Ekonomi solidaritas yang berbagi biaya, risiko, divisi kerja, pendidikan kritis, dan komunitas adalah kuncinya (Fikri, 2015; Shabia, 2019).

Poin lain seperti rantai pangan yang pendek serta model pasar tertutup merupakan cara lain yang dapat memberikan opsi bagi petani untuk memperoleh harga yang tidak dipermainkan pasar karena jumlah pendapatan yang tetap, setidaknya dalam satu masa keanggotaan. Pertanian berkelanjutan dengan promosi pangan lokal yang sehat merupakan sebuah cara untuk melepas ketergantungan petani dari sumber daya atau input eksternal, seperti pupuk dan pestisida yang dipasarkan perusahaan agrokimia yang menimbulkan kerusakan ekologis dan masalah ekonomi. Biaya produksi pun bisa ditekan ketika petani beralih ke pengelolaan sumber daya secara mandiri dan alami.

Kalaupun petani masih memerlukan bantuan, bantuan ini dapat diperoleh dengan kemampuan petani CSA berjejaring dan bekerjasama dengan petani lain yang turut bergerak dalam pertanian berkelanjutan dan bersedia bertukar sarana produksi yang independen. Ini lah yang disebut dengan proses "re-grounding" atau "membumikan kembali" (Van der Ploeg, et al., 2012). Beberapa gerakan agraria di Indonesia telah menerapkan pertanian organik seperti ini, sebagai contoh Serikat Petani Indonesia (SPI) atau Komunitas Swabina Pedesaan Salassae (KSPS) (Anugrah, 2019).

Tabel 1. Permasalahan Utama Dalam Pertanian Konvensional yang Ditanggulangi CSA

\begin{tabular}{|c|c|c|c|}
\hline & & Pertanian Konvensional & Pertanian CSA \\
\hline \multirow[t]{4}{*}{1} & \multirow{4}{*}{$\begin{array}{l}\text { Pendapatan bersih } \\
\text { yang diperoleh petani } \\
\text { kecil/pendapatan } \\
\text { hanya untuk bertahan }\end{array}$} & $\begin{array}{l}\text { Biaya produksi tinggi dan dibebankan pada } \\
\text { petani. Khusus petani penggarap: biaya } \\
\text { sewa tinggi. }\end{array}$ & $\begin{array}{l}\text { Biaya produksi ditanggung bersama-sama, } \\
\text { termasuk biaya sewa. }\end{array}$ \\
\hline & & $\begin{array}{l}\text { Pasar memengaruhi harga jual petani. } \\
\text { Fluktuatif. }\end{array}$ & $\begin{array}{l}\text { Pasar tertutup dan jelas jumlahnya untuk satu } \\
\text { periode kontrak (disepakati) }\end{array}$ \\
\hline & & $\begin{array}{l}\text { Kegagalan/risiko panen memengaruhi } \\
\text { pemasukan yang diterima petani }\end{array}$ & $\begin{array}{l}\text { Kegagalan/risiko panen (selama masih karena } \\
\text { faktor eksternal dan bukan kesalahan petani) } \\
\text { tidak memengaruhi pemasukan yang diterima } \\
\text { petani. }\end{array}$ \\
\hline & & $\begin{array}{l}\text { Ketergantungan terhadap sarana produksi } \\
\text { berpengaruh terhadap biaya produksi }\end{array}$ & $\begin{array}{l}\text { Pertanian alami; input pertanian seperti pupuk } \\
\text { dihasilkan sendiri dan benih dimuliakan/ } \\
\text { membeli dari jejaring petani. }\end{array}$ \\
\hline \multirow[t]{3}{*}{2} & \multirow{3}{*}{$\begin{array}{l}\text { Hubungan antara } \\
\text { konsumen dan } \\
\text { produsen }\end{array}$} & $\begin{array}{l}\text { Petani dan konsumen terpisah dalam } \\
\text { rantai yang panjang }\end{array}$ & $\begin{array}{l}\text { Petani dan konsumen terhubung dalam rantai } \\
\text { yang pendek dan relasi yang langsung }\end{array}$ \\
\hline & & $\begin{array}{l}\text { Petani dan konsumen tidak mengetahui } \\
\text { keadaan/kebutuhan satu sama lain }\end{array}$ & $\begin{array}{l}\text { Petani dan konsumen memiliki pengetahuan } \\
\text { atau pemahaman satu sama lain yang lebih utuh }\end{array}$ \\
\hline & & Komoditas/jenis pangan mengikuti pasar & $\begin{array}{l}\text { Diversifikasi dan penentuan komoditas pangan } \\
\text { yang dikehendaki; promosi pangan lokal }\end{array}$ \\
\hline
\end{tabular}

Sumber: Catatan lapangan penulis, 2020

Selain itu, terdapat satu hal yang menjadi poin penting CSA yang dapat berkontribusi bagi gerakan agraria di Indonesia, menyadari bahwa saat ini gerakan agraria di Indonesia juga bukan hanya bergerak dalam mobilisasi massa, pendudukan, advokasi, tetapi mulai bergerak ke ranah produksi pengetahuan kritis dan juga pengorganisasian ekonomi akar rumput dalam sektor pertanian (Anugrah, 2019). CSA menciptakan ruang untuk mendefinisikan kembali hubungan antara produsen dalam sistem pangan, dan ruang untuk "belajar" secara kritis, bukan hanya antara produsen dan konsumen, tetapi produsen dengan produsen. Bukan hanya pengorganisasian di pedesaan, tetapi pengorganisasian yang berpijak dalam hubungan pedesaan-perkotaan.

Bagi konsumen, telah dilihat dari Garten Coop bahwa partisipasi aktif anggota dalam CSA membuat mereka menyadari proses "di balik" sebuah komoditas. CSA mengenakan politik ruang yang 
membuat sebuah pangan bisa dibayangkan asalnya, tidak "aspasial" sebagaimana pangan-pangan dari "imperium bisnis pangan" (Van der Ploeg, et al., 2012) yang tidak diketahui siapa petaninya dan bagaimana kesejahteraannya. Dalam hal ini, Garten Coop telah mengikutsertakan konsumen ke dalam sebuah sirkuit produksi dan distribusi yang biasanya tidak melibatkan, bahkan tidak diketahui, konsumen. Anggota Garten Coop bisa merefleksikan soal perubahan iklim terhadap pertanian di CSA. Bukannya tidak mungkin, dalam konteks Indonesia, CSA juga dapat dijadikan ruang untuk mengajak anggota konsumen merefleksikan permasalahan agraria dari "keranjang sayuran" dan "piring" dengan menghubungkan mereka pada petani yang menghadapi masalah ini dalam kesehariannya. Pengetahuan ini tentu tak terlepas dari kondisi konsumen urban yang juga menghadapi sisi buruk lain dari adanya rezim pangan korporasi berikut pertanian industrial: permasalahan kesehatan seperti penyakit tidak menular karena diet pangan murah—kebanyakan makanan ultraproses—yang tinggi garam, gula, dan lemak. Dari sisi produsen, ini bisa dibaca sebagai pembentukan pasar yang baru, relasi pertukaran desakota yang baru (Van der Ploeg, 2019).

Di antara produsen, CSA dapat menjadi wahana pendidikan kritis tempat petani-petani dapat mempelajari pertanian berkelanjutan. Makna "mempelajari” tidak terbatas dalam artian harfiah seperti metode kelas atau pendidikan yang kaku, tetapi pendidikan informal seiring menjalankan kegiatan CSA. Garten Coop, serta beberapa studi CSA lainnya telah membuat petani-petani muda memaknai CSA bukan hanya sebagai wadah untuk bertani tanpa tekanan, tetapi juga wahana untuk mempelajari pertanian alami (Partszch, 2018; Holt-Giménez, 2010). Dengan asumsi bahwa petani pemilik lahan sebagai inisiator atau tim inti yang menjalankan CSA telah berkiprah dalam pertanian alami, kemudian CSA ini merekrut satu-dua petani penggarap lain atau buruh tani yang diajarkan pertanian alami untuk mengelola lahan, pendidikan kritis dapat tercipta.

Ada sebuah kemungkinan menarik apabila petani-petani yang dalam kelas sosial di pedesaan dikategorikan sebagai buruh tani masuk ke CSA dan kemudian dimodali untuk menggarap lahan lain dengan pertanian berkelanjutan. Surplus dari CSA bisa di-“akumulasi” untuk menciptakan kemungkinan ini, yakni ditabung untuk memodali petani CSA berikutnya.

Bagaimana petani mengakumulasi surplus dalam skema "pasar yang baru berkembang" (newly emerging market) atau nested market (Van der Ploeg, et al., 2012) dapat menjadi model pengalihan surplus yang diterapkan dalam CSA. CSA juga dapat bekerjasama dengan koperasi petani atau kelompok tani untuk menggandeng lebih banyak petani dalam memulai CSA. Jejaring yang saling bertukar sumber daya, pengalaman, sekaligus keahlian dengan petani-petani baru atau petani lama yang bergerak dalam pertanian alami dapat terbentuk, mirip dengan semangat campesino-a-campesino (McMichael, 2020; Holt-Giménez, 2010). Bukan hanya hal ini akan menciptakan mobilitas "ke atas" dalam kelas sosial petani, tetapi dapat memperluas gerakan petani kecil yang menguasai sumber-sumber agraria dan mengelolanya dengan pertanian berkelanjutan.

Tentang pendidikan kritis produsen ke konsumen dan produsen ke produsen ini terlihat sebagai sesuatu yang kurang signifikan. Apalagi melihat bahwa kecenderungan konsumen yang digandeng CSA segmentasinya akan (lebih banyak) berasal dari kelas menengah atas, menengah, atau pekerja di perkotaan. Namun di sini lah letak perjuangan CSA dilihat dari kacamata yang lebih besar. Bahwa sebagai gerakan yang basisnya adalah identitas atau aktivisme, bukan kelas, CSA tetap memiliki standpoint sebagai gerakan anti-kapitalis yang menentang sistem pangan global pemicu ketimpangan.

Inisiatif ini tetap berusaha untuk menawarkan penataan ulang dan pola kemitraan alternatif bagi petani untuk bertahan dalam situasi-situasi tertentu hingga reforma agraria benar-benar dijalankan. Mereka juga berusaha untuk masuk ke tataran personal konsumen dan memberikan "food from somewhere" (McMichael, 2009b) dengan harapan semakin banyak orang yang bersolidaritas dengan petani. Dalam hal ini, argumentasi Borras (2019) soal perjuangan mewujudkan "gerakan sosial agraria" 
yang berusaha merengkuh sebanyak mungkin orang dan gerakan ke dalam "populisme agraria" menjadi penting sebagai pijakan untuk melihat signifikansi CSA. Menurut Borras, keberadaan kelas-kelas (sosial) yang berbeda dan identitas sosial yang beririsan dalam satu gerakan yang menentang kapitalisme dan memperjuangkan pembangunan alternatif berorientasi petani bukanlah sebuah masalah. Hanya saja, dalam mencapai perubahan struktural, kesatuan gerakan ini harus menyandang ${ }_{5} \mathrm{R}$ : redistribusi, rekognisi, restitusi, regenerasi, dan resistensi (lihat Borras, 2019).

CSA dapat berkontribusi dengan gerakan agraria sebagai bagian dari perjuangan populisme agraria, selama "disconnected nature"-nya diubah, ditempatkan sebagai a means to an end, saluran mencapai tujuan yang sebenarnya. Dengan maksud, CSA harus didudukkan pada pertanyaan: ditempatkan di mana ia dalam perjuangan agraria? Dan kepentingan agraria seperti apa yang harus dimasukkan dalam CSA?

Pertama, CSA dapat ditempatkan di awal perjuangan agraria: yakni membantu petani tetap bertahan dalam usaha taninya dan menjamin aksesnya. Prinsip pasar tertutup bisa menimbulkan kestabilan pendapatan untuk petani, dengan pengalihan surplus sebagai cara untuk memperbanyak jumlah petani yang dibantu aksesnya ke lahan, sekaligus sebagai sarana "pendudukan" lahan-lahan di berbagai tempat dan pengorganisasian petani dalam gerakan.

Kedua, CSA juga dapat ditempatkan setelah reforma agraria terjadi. Selama ini selalu muncul pertanyaan atau keprihatinan seputar apa yang harus dilakukan pasca redistribusi atau pendudukan tanah telah berhasil (Anugrah, 2019), terutama setelah pengalaman pahit Kampanye Sagara, di mana hak atas tanah yang sudah dimenangkan malah berujung pada penjualan dan penggadaian tanah yang dimiliki secara individual (lihat Peluso, et al, 2008). Solusi yang kerap diambil adalah kepemilikan komunal untuk produksi pertanian bersama (Anugrah, 2019), tetapi tantangannya sangat besar menilik tidak semua masyarakat pedesaan memiliki karakteristik komunitarian dan egalitarian, serta adanya elit-elit desa, mafia tanah, dan korporasi yang agresif dalam mengakumulasi lahan di pedesaan (Li, 2021). Pertanian bermodel CSA setidaknya dapat menjadi alternatif untuk melindungi "ancaman" yang masih akan terus hadir dalam keterhimpitan petani yang ingin menjual tanahnya untuk memperoleh uang (Gilbert dan Afrizal, 2019 dalam Li, 2021).

Dalam mengemban kepentingan gerakan agraria, CSA memang memiliki keterbatasan untuk bergerak dalam tataran advokasi kebijakan, sehingga untuk mencapai dimensi ini, ia harus beraliansi dengan gerakan agraria yang "sebenarnya". Apalagi, menyadari kondisi relasi tenurial di Indonesia masih cukup memberatkan biaya produksi karena biaya sewa dan harga tanah yang tinggi. Ini menyebabkan perjuangan menyediakan akses lahan bagi petani akan tetap sulit selama redistribusi tanah tidak diperjuangkan. Adanya konflik agraria dan perampasan lahan yang dikomandoi negara bersama korporasi juga menghantui dan CSA pun tidak imun dengan perampasan-perampasan seperti ini tanpa reforma agraria.

Setidaknya, untuk saat ini, CSA dapat mendukung gerakan agraria dengan merangkul sebanyakbanyaknya petani dan konsumen untuk saling bersolidaritas serta memasukkan produksi pengetahuan kritis termasuk kesadaran soal permasalahan agraria kepada anggota-anggotanya. Dibutuhkan tim inti beranggotakan petani dan konsumen yang memiliki, bukan hanya pengetahuan terkait permasalahan agraria, pangan, dan pertanian, tetapi juga kapasitas teknis tentang pertanian alami yang dapat memasukkan nilai-nilai perjuangan demi memperbaiki penghidupan petani sebanyak-banyaknya dan menyebarkan produksi pengetahuan soal permasalahan agraria seluas-luasnya.

\section{Kesimpulan}

Telah kita lihat bahwa Community Supported Agriculture (CSA) merupakan salah satu gerakan pangan dengan model pertanian alternatif yang dapat memberikan opsi bagi petani untuk bertahan 
hidup, baik dengan memperoleh pendapatan yang stabil tanpa tekanan pasar, hingga melangsungkan usaha tani melalui ekonomi solidaritas. Terhadap kontribusinya dengan gerakan agraria di Indonesia, CSA dapat memainkan peranan penting selama gerakan ini diarahkan untuk berfokus pada pengorganisasian petani dan konsumen dalam pendidikan kritis soal permasalahan pangan dan agraria, serta menggunakan surplusnya untuk memperluas lahan-lahan yang akan "diduduki" dengan model CSA.

Mencoba menghubungkan model CSA yang banyak berkembang di negara-negara Global Utara, dalam hal ini Jerman, dengan konteks di Indonesia adalah sebuah harapan yang mesti diujicobakan di lapangan dan kemungkinan besar memiliki hasil yang berbeda dari apa yang sudah ditulis dalam artikel ini. Sebagai catatan kritis, tulisan ini tentu belum membedah kemungkinan-kemungkinan menjadikan CSA lebih inklusif untuk lebih merangkul kelas pekerja, buruh, dan kaum miskin di perkotaan, dalam artian tidak hanya tersegmentasi pada konsumen kelas menengah atau menengah ke atas yang teredukasi sebagai sumber daya paling utama untuk ekonomi CSA. Selain itu, artikel ini juga masih membayangkan bahwa gerakan CSA ini paling mungkin dibentuk di daerah-daerah pedesaan yang letaknya tidak terlalu jauh atau dapat diakses dengan mudah dari kota karena karakteristik hubungan desa-kotanya tadi. Ini lantas membawa pada pemahaman bahwa tidak semua lahan pangan di seluruh daerah dapat dibentuk sebagai CSA.

Meskipun begitu, kemunculan gerakan solidaritas terhadap petani dalam masa pandemi Covid-19, mulai dari gerakan yang membeli hasil petani untuk dihubungkan kepada konsumen seperti gerakan Genduli (Gelanggang Peduli Petani) dan Panen Apa Hari Ini di Yogyakarta, hingga gerakan buruh-tani Gerakan Solidaritas Lumbung Agraria atau GeSLA bentukan Konsorsium Pembaruan Agraria (KPA), yang telah mendistribusikan hasil panen organisasi tani anggota KPA terhadap konsumen prioritas seperti buruh dan masyarakat miskin perkotaan (KPA, 2020), menjadi sebuah harapan bahwa CSA dapat dibentuk dan merangkul kelompok rentan perkotaan. Saat ini, juga sedang berkembang pula dua project CSA di dua tempat: Sukabumi dan Yogyakarta, di mana inisiatornya merupakan petani muda yang mempelajari pertanian berkelanjutan, yang dapat diarahkan pada solusi dari permasalahan soal regenerasi petani di Indonesia (White, 2012; 2015).

Tentunya, kemunculan gerakan-gerakan ini memberikan harapan terciptanya sebuah CSA yang menerapkan ekonomi solidaritas, yang menjadi sebagian kecil perjuangan dari perjuangan agraria yang sebenarnya: di mana bumi, air, udara, dan sumber daya di atasnya diperuntukkan bagi sebesar-besarnya kesejahteraan rakyat, termasuk dalam pemenuhan pangan yang layak baik bagi produsen skala kecil, maupun konsumen.

\section{E. Ucapan Terima Kasih}

Artikel ini merupakan bagian dari skripsi di Departemen Antropologi Budaya yang berjudul, "Mengonsumsi Melawan Arus: Praktik dan Signifikansi Solidaritas dalam Dua Komunitas Pertanian Solidarische Landwirtschaft (Solawi) di Freiburg, Jerman”. Program Riset Tandem yang menjadi sumber data skripsi dan artikel ini didukung oleh pendanaan dari Departemen Antropologi Budaya Universitas Gadjah Mada. Ucapan terima kasih dihaturkan kepada departemen, Prof. Dr. Pujo Semedi (Universitas Gadjah Mada) dan Prof. Dr. Judith Schlehe (Albert-Ludwigs-Universität (ALU) Freiburg) yang telah menjadi supervisor kegiatan, sekaligus Dr. Agung Wicaksono yang telah menjadi dosen pembimbing hingga skripsi ini telah diujikan dan dinyatakan memenuhi syarat kelulusan.

\section{Daftar Pustaka}

Allen, P., FitzSimmons, M., Goodman, M., Warner, K. (2003). Shifting plates in the agrifood landscape: the tectonics of alternative agrifood initiatives in California. Journal of Rural Studies, 19, 61-75 
Ambarwati, A., Harahap, R. A., Sadoko, I., \& White, B. (2016). Land Tenure and Agrarian Structure in Regions of Small-Scale Food Production. In J. F. McCarthy \& K. Robinson (Eds.), Land and Development in Indonesia: Searching for the People's Sovereignty (pp. 265-294). Singapore: ISEAS. Anugrah, I. (2014). Movements for Land Rights in Democratic Indonesia. In T. Dibley \& M. Ford (Eds.), Activists in Transition: Progressive Politics in Democratic Indonesia (pp. 79-98). Cornell University Press.

Badan Pusat Statistik. (2017). Hasil Survei Struktur Ongkos Usaha Tanaman Padi. Diakses dari https:// www.bps.go.id/publication/2017/12/26/o7cao64175333cd9f796c183/hasil-survei-struktur-ongkosusaha-tanaman-padi-2017.html.

Badan Pusat Statistik. (2019a). Hasil Survei Pertanian Antar Sensus (SUTAS) 2018. Badan Pusat Statistik, diakses dari https://www.bps.go.id/publication/2019/10/31/9567dfb39bd984aa45124b4o/hasilsurvei-pertanian-antar-sensus--sutas--2018-seri-a2.html

Badan Pusat Statistik. (2019b). Hasil Survei Struktur Ongkos Usaha Tanaman Hortikultura (SOUH) 2018. Diakses dari https://www.bps.go.id/publication/2019/11/27/2912ea42bb3ooaf3467c62d4/ hasil-survei-struktur-ongkos-usaha-tanaman-hortikultura-2018.html

Bernstein, H. (2019). Dinamika Kelas dalam Perubahan Agraria. Yogyakarta: Insist Press

Borras, S. M. (2018). Agrarian social movements: the absurdly difficult but not impossible agenda of defeating right-wing populism and exploring a socialist future. J Agrar Change, 1-34. DOI: 10.1111/ joac.12311

Buechler, S. M. (2013). New social movements and new social movement theory. In D. A. Snow, D. della Porta, B. Klandermans, \& D. McAdams (Eds.), The Wiley-Blackwell Encyclopedia of Social and Political Movements. DOI: 10.1002/9781405198431.wbespm143

Eaton, C., Shepherd, A., (2001). Contract Farming: Partnerships for Growth. Service Bulletin No. 145. Rome: Food \& Agriculture Organisation of the UN.

Feagan, R., dan Henderson, A. (2009). Devon Acres CSA: local struggles in a global food system. Agric Hum Values, 26, 203-2017. DOI 10.1007/s10460-008-9154-9

Fikri, M.A.A. (2015). Ekonomi Solidaritas dalam Gerakan Sosial Baru: Pengalaman Garten Coop di Freiburg, Jerman (Skripsi S1). Universitas Gadjah Mada. Yogyakarta.

Folbre, N. (2013, July 29). Fast Food Versus Slow Food. The New York Times: Economix. Diakses dari https://economix.blogs.nytimes.com/2013/o7/29/weighing-home-cooking-and-take-out/

Galt, R., Beckett, J., \& Hiner, C.C. (2011). Community Supported Agriculture (CSA) in and around California's Central Valley: Farm and Farmer Characteristics, Farm-Member Relationships, Economic Viability, Information Sources, and Emerging Isuses. University of California Davis. Diakses dari https://escholarship.org/uc/item/6rg7r36w

Garten Coop. (2018a). GartenCoop Freiburg: Gudielines for Intern (and New Members). Unpublished Document.

Garten Coop. (2018b). Garten Coop presentation by Luciano Ibarra. Unpublished Document.

Garten Coop. n.d. "Self-image - basic position paper". Accessed from https://www.gartencoop.org/ tunsel/node/5088 Diakses 6 Juni 2021.

Goland, C. (2002). Community Supported Agriculture, Food Consumption Patterns, and Member Commitment. Culture \& Agriculture, 24(1), 14-25

Henderson, E. (2010). The World of Community Supported Agriculture. Keynote for Urgenci Kobe Conference 2010, "Community Supported Foods and Farming". Diakses dari https://base.socioeco. org/docs/the_world_of_community_supported.pdf

Hinrichs, C. C. (200o). Embeddedness and local food systems: notes on two types of direct agricultural market. Journal of Rural Studies, 32, 230-239.

Hinrichs, C., \& Kremer, K. S. (2008). Social Inclusion in a Midwest Local Food System Project. Journal of Poverty, 6(1), 65-9o. DOI 10.1300/J134Vo6no1_04 
Holt-Giménez, E., Bunch, R., Vasques, J. I., Wilson, J., Pimbert, M. P., Boukary, B., \& Kneen, C. (2010). Linking farmers' movements for advocacy and practice. The Journal of Peasant Studies, 37((1), 203-236. DOI 10.1080/03066150903499943

Holt-Holt-Giménez, E., dan Shattuck, A. (2011). Food crises, food regimes and food movements: rumblings of reform or tides of transformation?. The Journal of Peasant Studies, 38(1), 109-144. DOI: $10.1080 / 03066150.2010 .538578$

Japan Organic Agriculture Association. (n.d.). In Pursuit of Food, how we should farm, eat, and live today. Diakses dari https://www.1971joaa. org/\%E6\% ${ }_{9} \mathrm{C} \% \mathrm{AC} \% \mathrm{E}_{4} \% \mathrm{BC} \% 9 \mathrm{~A} \% \mathrm{E}_{3} \% 81 \% \mathrm{AB} \% \mathrm{E}_{3} \% 81 \% \mathrm{~A}_{4} \% \mathrm{E}_{3} \% 81 \% 84 \% \mathrm{E}_{3} \% 81 \% \mathrm{A6} /$ about-us/ about-us-html/, 3 Juli 2021.

Kalfagianni, A., \& S. Skordili. (2018). Localizing global food: An introduction. A. Kalfagianni, \& S. Skordili (Eds.). Localizing Global Food: Short Food Supply Chains as Responses to Agri-food System Challenges. London dan New York: Routledge

Konsorsium Pembaruan Agraria. (2020). Silaturahmi Gerakan Buruh-Tani, Bangun Kekuatan Ekonomi Rakyat Melalui GeSLA. Diakses dari http://kpa.or.id/media/baca/kegiatan/536/Silaturahmi_ Gerakan_Buruh-Tani_Bangun_Kekuatan_Ekonomi_Rakyat_Melalui_GeSLA/, 10 Juli 2021.

Li, T. M. (2020). Kisah dari Kebun Terakhir: Hubungan Kapitalis di Wilayah Adat. Tangerang Selatan: Marjin Kiri.

Li, T. M. (2021). Commons, co-ops, and corporations: assemling Indonesia's twenty-first century land reform. The Journal of Peasant Studies, 48(3), 613-639. DOI: 10.1080/03066150.2021.1890718

MicMichael, P. (2009a). Food sovereignty, social reproduction, and the agrarian question. Peasants and Globalization: Political economy, rural transformation and the agrarian question. Akram Lodhi, A. H., dan Kay, C (eds). London and New Yourk: Routledge.

McMichael, P. (2009b). A food regime genealogy. The Journal of Peasant Studies, 36 (1), 139-169.

McMichael, P. (2020). Rezim Pangan dan Masalah Agraria. Yogyakarta: Insist Press

Neilson, J. (2016). Agrarian transformations and land reform in Indonesia. Dalam J. F. McCarthy \& K. Robinson (Eds.), Land and Development in Indonesia: Searching for the People's Sovereignty (hlm. 245-264). Singapore: ISEAS.

Medici, M., Canavari, M., Castellini, A. (2021). Exploring the economic, social, and environmental dimensions of community-supported agriculture in Italy. Journal of Cleaner Production, 316, 1-9. DOI: 10.1016/j.jclepro.2021.128233

Melucci, A. (1980). The new social movements: A theoretical approach. Social Science Information, 19 (2), 199-226. DOI: 10.1177/053901848001900201

Ostrom, M. R. (1997). Toward a Community Supported Agriculture: A Case Study of Resistance and Change in the Modern Food System (Disertasi S3). University of Wisconsin. Madison.

Ostrom, M. R. (2007). Community Supported Agriculture as an Agent of Change: Is it Working?. Dalam C. Hinrichs \& T. Lyson (Eds.), Remaking the North American Food System (hlm. 99-120). University of Nebraska Press.

Partzch, L. (2018). Food localization and agency: the cases of Regionalwert AG and Luzernenhof in Freiburg, Germany. Dalam A. Kalfagianni, \& S. Skordili (Eds.), Localizing Global Food: Short Food Supply Chains as Responses to Agri-food System Challenges (hlm. 55-69). London and New York: Routledge

Peluso, N. L., Afiff, S., \& Rachman, N. F. (2008). Claiming the Grounds for Reform: Agrarian and Environmental Movements in Indonesia. Journal of Agrarian Change, 8 (2 \& 3), 377-407

Pichardo, N. A. (1997). New Social Movements: A Critical Review. Annu. Rev. Social, 23, 411-430

Plank, C., Hafner, R., \& Stotten, R. (2020). Analyzing values-based modes of production and consumption: Community-supported agriculture in the Austrian Third Food Regime. Österreich Z Soziol, 45, 49-68. Diakses dari https://doi.org/10.1007/s11614-020-00393-1 
Ray, N., Clarke, G., Waley, P. (2021). The impact of contract farming on the welfare and livelihoods village casestudy from West Bengal.Journal of Rural Studies, 86, 127-135. DOI:10.1016/j.jrurstud.2021.06.003

Schlicht, S., Volz, P., Weckenbrock, P., \& Le Gallic, T. (2014). Community Supported Agriculture: An overview of characteristics, diffusion and political interaction in France, Germany, Belgium, and Switzerland. Diakses dari http://www.agronauten.net/wp-content/uploads/2014/o3/CommunitySupported-Agriculture-An-overview-of-characteristics-diffusion-and-political-interaction-inFrance-Germany-Belgium-and-Switzerland.pdf

Shabia, G. N. A. (2019). Mengonsumsi Melawan Arus: Praktik dan Signifikansi Solidaritas dalam Dua Komunitas Pertanian Solidarische Landwirtschaft (SOLAWI) di Freiburg, Jerman (Skripsi S1). Universitas Gadjah Mada. Yogyakarta.

Teubal, M., \& Breña, M. O. (2009). Agrarian Reform and Social Movements in the Age of Globalization: Latin America at the Dawn of the Twenty-first Century. Latin American Perspectives, 36(5), 9-20. Diakses dari https://www.jstor.org/stable/20684655

Van der Ploeg, J. D. (2010). The Food Crisis, Industrialized Farming and the Imperial Regime. Journal of Agrarian Change, 10(1), 98-106

Van der Ploeg, J.D., Ye, J., \& Schneider, S. (2012). Rural development through the construction of new, nested, markets: comparative perspectives from China, Brazil, and the European Union. The Journal of Peasant Studies, 39(1), 133-173

Van der Ploeg, J. D. (2019). Petani dan Seni Bertani: Maklumat Chayanovian. Yogyakarta: Insist Press.

White, B. (2012). Agriculture and the Generation Problem: Rural Youth, Employment and the Future of Farming. IDS Bulletin, 43 (6), 9-19

White, B. (2015). Generational dynamics in agriculture: reflections on rural youth and farming futures. Cah Agric, 24(6), 330-334. DOI 10.1684/agr.2015.0787 